УДК 159.9

DOI: $10.33099 / 2617-6858-2019-53-3-119-132$

Семенов С. кандидат філософських наук, доцент,

Начіональна академія Начіональної гвардії України

ORCID ID 0000-0003-4134-0194

Слурденко Д. Наиіональна академія

Національної гвардії України

ORCID ID 0000-0001-8080-7805

Шевченко В. Національна академія

Національної гвардії України

ORCID ID 0000-0003-3066-4361

\title{
ПСИХОЛОГІЧНИЙ АНАЛІЗ ПРОБЛЕМИ СУЇЦИДАЛЬНОЇ ПОВЕДІНКИ ВІЙСЬКОВОСЛУЖБОВЦІВ
}

Зроблена спроба розкрити загальне поняття суїииду, дати психологічну характеристику основних складових суйщидальної поведінки військовослужбовия та розглянути організацію психологічної роботи стосовно діагностики $і$ профілактики прояв самогубства членами військових колективів.

Ключові слова: суїицд; сочіально-психологічна дезадаптація; військовослужбовецьь.

Постановка проблеми. Актуальність теми даного дослідження очевидна. Згідно 3 прогнозом Всесвітньої організації охорони здоров'я (ВООЗ) до 2020 року, приблизно 1,5 млн. людей на землі помруть від суӥцидів. Статистика стверджує: щодня в Україні здійснюється близько 500 суїцидальних спроб, в результаті яких гине 35-40 осіб. У нас від самогубства вмирає людей більше, аніж гине від рук вбивць і під час транспортних аварій.

Здавна існує проблема суїциду в армії. Жорстка регламентація та вимогливість військової служби, значні психологічні та фізичні навантаження, перенесення ряду негативних явищ із суспільства в армійське середовище, гострий дефіцит кваліфікованих спеціалістів-психологів та інші причини провокують суӥцидальну поведінку у військовослужбовців.

Взагалі, природа i профілактика суїциду в армійському соціуму в стадії активного наукового вивчення.

Аналіз останніх досліджень i публікацій. Методологічну основу даної роботи склали відповідні праці: Е. Дюркгейма, 3. Фрейда, К. Юнга, К. Харні, М. Бердяєва, А. Амбрумової,
А. Моховікова,
В. Тихоненко,
С. Жабокрицького,
Т. Ларіної,

Т. Глушкової та інших дослідників. В ході висвітлення теми, нами використані також деякі методичні розробки вітчизняних фахівців, окремі ресурси інтернет-видань 3 означеної проблеми.

Мета статті. Мета дослідження полягає в розкриті загального поняття суїциду, дати психологічну характеристику основних складових суїцидальної поведінки військовослужбовця та розглянути організацію психологічної роботи стосовно діагностики i профілактики прояв самогубства членами військових колективів.

У статті знайшли відтворення наші власні спостереження i міркування, фактологічний матеріал, отриманий 3 різних офіційних джерел.

Методи дослідження. Аналіз, синтез, порівняння, узагальнення.

Наукова новизна дослідження. Удосконалено теоретико-психологічний підхід вивчення суїцидальної поведінки військовослужбовця та розглянуто організацію психологічної роботи стосовно діагностики i профілактики самогубств у військових колективах.

Виклад основного матеріалу. Для визначення сутності суїциду звернемось до наукових розробок цього поняття різними школами дослідників та 


\section{Питання психології}

відслідкуємо наявність усталених тенденцій або закономірностей практичних проявів самогубства.

В науковій літературі суїцид зазвичай трактується як усвідомлений вчинок людини вільно та навмисно лишити себе життя, як само руйнівна форма людської поведінки. Відповідно, суїцидальний ризик - це намір, потенційна готовність індивіда покінчити зі своїм життям. Суӥцидальною поведінкою прийнято називати будь-які внутрішні та зовнішні форми психічних активів, які пов'язані $з$ реальними уявленнями $\mathrm{i}$ вчинками стосовно особистого фізичного самознищення. Підставою для прийняття людиною рішення про самогубство $\epsilon$ суїцидогенний конфлікт, викликаний життєвою кризою. Під час такого конфлікту різко посилюється суб'єктивне переживання ефектної напруги, тривоги або суму, до «останньої краплі» виснажуються механізми психологічного захисту, втрачається сенс життя. Суӥцидогенний конфлікт складається 3 двох, по-різному спрямованих тенденцій. Одну тенденцію представляє актуальна в даний момент потреба людини, а іншу тенденція, яка перешкоджає іiі задоволенню. В колі вчених подібна невідповідність отримала назву протиріччя між бажаним і дійсним.

Неодмінно може виникнути слушне запитання: суїцид - це негативне чи позитивне явище, добро чи зло для конкретної людини і суспільства? Навіть серед відомих мислителів не має однозначності в оцінці самовбивства i самогубців. Так, наприклад Д. Дідро свого часу писав: «Загальновідомо, що інколи життя представляе собою суцільне нещастя. Коли істота дійшла до того, що бажає вмерти, не треба примушувати іiі жити» [2]. Подібної думки дотримується і японський дослідник суїцидів Ватару Цурумі, який видав книгу «Керівництво по самогубству». До речі, дана праця пережила більше 50-ти перевидань. Автор детально описав у ній всі шляхи і засоби зведення рахунків 3 життям. Взагалі ж його кредо наступне: «Кожен може вмерти тоді, коли він цього забажає. При такому виборі завжди життя здається набагато легшим. Людина - господар своєї долі, i якщо вона хоче розлучитись 3 життям, не варто ії зупиняти» [6].

Саме таке розуміння проблеми лежить в основі ідеї раціонального суїциду, яка сьогодні отримує розповсюдження в країнах Заходу. Правда iï носії стверджують, що суїцид може бути морально виправданим у двох випадках при невиліковній хворобі і при тяжкій фізичній інвалідизації.

А ось зовсім протилежна теза стосовно суїциду: «Самовбивець - це боягуз, котрий тікає до закінчення битви». Даний вислів належить Л. Бешерелю [2]. Певну вагу мають також наступні слова М. Бердяєва: «Коли людина вбиває себе тому що іiі чекають катування, а вона боїться здійснити зраду, то це, по суті, не $\epsilon$ навіть самовбивство. Самовбивство може бути від цілковитого безсилля і від надміру сили» [1].

$\mathrm{He}$ дивлячись на ці та інші міркування знаних осіб, в основній своїй масі суїцидальні наміри та вчинки відносяться, на наш погляд, до різновиду соціальної патології, психічної хвороби.

Існує декілька наукових концепцій самогубства. Вони базуються на соціологічних, психодинамічних, біологічних та гностичних орієнтаціях людської поведінки. Зокрема, сутність соціологічного напрямку у вивченні природи цього явища полягає в доказі того, що суїцид провокується виключно взаємодією між індивідом і навколишнім середовищем. Першим на важливість врахування соціального контексту при здійсненні суїциду вказав Е. Дюркгейм. В соціальному етюді «самогубство» він стверджував, що самогубство може бути краще пояснене, як реакція людини на особливості товариства, в якому вона живе. Згідно 3 його теорією є три види суїцидів.

Перший вид - це егоїстичні суїциди, коли саморуйнування обусловлюється тим, що індивід почуває себе відчуженим і роз'єднаним із товариством, родиною, друзями. 


\section{Питання психології}

Другий вид - анемічні суїциди, що виникають, якщо людина зазнає невдачу в адаптації до соціальних змін.

Третім видом виступають альтруїстичні самогубства, коли індивід жертвує себе заради суспільних інтересів.

В психологічних теоріях стверджується, що суїцид - це лише продукт внутрішніх мотивів індивіда, в основі яких лежить тривога, провина, гнів, безпорадність і т. п. Серед авторів реальної спроби психологічного тлумачення слід назвати засновника психоаналітичної теорії 3. Фрейда. У своій роботі «Сум і меланхолія» він виділяє два типи людських потягів: один 3 них інстинкт до життя - Ерос, інший інстинкт або потяг до смерті, руйнування, агресії - Танатос. Згідно 3 теорією 3. Фрейда, відбуваються постійні коливання між силою цих двох інстинктів. Самовбивство і вбивство інших людей являють собою прояв імпульсивного i руйнівного впливу Тонатоса.

Представники біологічної концепції єдині в тому, що суїцид є генетичною схильністю, яку людина отримує у спадщину.

Гностичний підхід в науці до цього явища обгрунтовує - мотиви суїциду в спробі спілкування або вирішення іншої гострої проблеми в умовах, коли неможливо позбутися комунікативного вакууму.

$\begin{array}{cr}\text { На нашу думку } & \text { прихильності } \\ \text { заслуговує } & \text { новий, }\end{array}$ сформований російськими фахівцями в галузі суїцидології соціальнопсихологічний підхід при визначенні природи суїциду. Послідовники цієї концепції вбачають першопричину, джерело суїциду в душевному неблагополуччі людини, пов'язаному насамперед зі складністю іiі буття, або говорячи іншими словами, в соціальнопсихологічній дезадаптації індивіда в умовах гострої мікросоціальної конфліктної ситуації. За умови суб'єктивно тяжких обставин саме негативні психічні стани унеможливлюють для людини конкретне вирішення особистих проблем i штовхають іï до крайньої межі - лишитися життя. Перехід від дезадаптації до суїдального вчинку залежить, як правило, від наявності двох обставин: якщо у людини відсутні буд-які варіанти розв'язання конкретного конфлікту або якщо наявні варіанти рішень вона розцінює як неефективні чи неприйнятні.

Для більш глибшого пізнання проблеми бажано, на наш погляд, у проявах суїцидальності відстежити усталені тенденції або закономірності.

Як вважають психологи, мета, завдання, стимули, методи реалізації суїцидальної поведінки та інше, властиві усім самогубствам і самогубцям.

Так, загальною метою суӥцидів виступає пошук рішення по виходу із кризового стану. Такому пошуку властива своя логіка і доцільність. Щоб зрозуміти причину суїциду, слід віднайти проблеми, для розв'язання яких він був призначений.

Загальним завданням усіх суӥцидів $€$ припинення душевного болю. Відповідно до цього суїцид складається 3 трьох частин - наявності у людини, що впала у відчай постійного хвилювання, підвищеного рівня тривоги i високого летального потенціалу.

Загальним стимулом при суїциді виступає нестерпний психічний біль, від якого людина намагається втекти раз i назавжди.

Загальним стресором при суїциді є не задоволені психологічні потреби.

Загальною суїцидальної емоцією виступає безпорадність, безнадійність. В цьому стані людина начебто констатує: «Я нічого не можу зробити, крім самогубства, i ніхто не може мені допомогти, щоб полегшити біль, який я постійно відчуваю».

Загальним внутрішнім відношенням до суїциду являється суперечливість, амбівалентність - людина відчуває потребу у здійснені самогубства i водночас бажає порятунку і втручання в іiі стан інших.

Загальною дією при суїциді стає втеча, щоб відображає намір індивіда покинути зону нещастя. Тому суїцид вважають радикальною межовою, 


\section{Питання психології}

остаточною зміною обставин або своєрідних декорацій.

Загальною рисою суїциду виступає відповідність суїцидальної поведінки стилю i характеру попереднього життя людини.

Так, науковцями доведено, що самогубство мало місце у всі часи. Правда ставлення до нього протягом епох було різне i часто залежало від пануючих релігійних поглядів та морально-етичних норм і традицій. Найдавніші самогубства носили, як правило, ритуальний характер, вони заохочувались суспільством, а ухилення від них вважалось великою ганьбою. Прикладами ритуальних самогубств є добровільне принесення себе в жертву богам, а також харакірі, сепуку i саті (обряд самоспалення індійських вдів). 3 появою християнства відношення до самовбивства стає різко негативним, церква оголошує його гріховною справою. У святому писанні говориться: «Якщо Бог дарує життя, то не можна легковажно поводитись 3 ним, а тим паче кидати цей дар до божих ніг, треба намагатися прожити відведений кожному відрізок часу до кінця». Життя оцінюється християнською релігією не задоволенням, a стражданнями (заради майбутнього існування в потойбічному світі).

Самогубство - це хвороба, властива багатим i не прокляття бідняків. Воно дуже «демократичне» i розподіляється пропорційно серед людей незалежно від їхнього майнового стану, матеріального забезпечення тощо. Це ж саме стосується розвинутих і відсталих в соціальноекономічному відношенні країн. А ось «різкі повороти» в розвитку як перших, так і других можуть давати певні спалахи суїцидальності.

Самогубство має своє свої статеві переваги та вікові піки. Рівень суӥцидів серед чоловічої статі завжди $є$ вищим, аніж серед жіночої. Співвідношення чоловіків і жінок, які зводять рахунки 3 життям, становить 4:1 [1]. Статично виявлено два основні вікові піки суїцидентів: це пік молодості - від 15 до 23 років, і пік інволюції - після 40 років.
Невеликий відсоток самовбивць серед людей, що відвідують церкву.

Для суїцидентів має значення і пора року: найбільше самогубств реєструється навесні і під час різдвяних свят.

Ідея суїциду у людей рідко виникає випадково, вона визріває певний час. У суїцидальній поведінці будь-якої категорії громадян можна умовно виділити 3 фази:

а) фаза обдумування суӥцидального вчинку;

б) фаза підготовки до скоєння самогубства;

в) фаза практичної суїцидальної спроби.

Фіксується високий ризик суїциду у людей, які перебувають в екстремальних умовах хвороба, голод, війна, природні та техногенні катастрофи тощо.

Причиною самогубства часто - густо виступають сімейні конфлікти. Взагалі суїцидальні прояви неможливо серйозно аналізувати поза контекстом будь-якого соціального оточення, в тому числі в сім'ї суїцидента. Обов'язково варто брати до уваги актуальні потреби, бажання та прагнення близьких, емоційний клімат сім'ї.

Рівень суїцидів також має прямий стосунок до процесів урбанізації суспільства.

Багато самогубств $є$ наслідком швидкозмінних умов існування людей в суспільстві, що характерно і для України. Основні їх причини лежать у економічній, соціальній та психологічній сферах, а також пов'язані 3 безробіттям, втратою перспективи в житті, алкоголізмом, наркоманією і т.п.

Чимала кількість тих, хто вирішив стати на шлях самовбивства. Залишають передсмертні записки. Мабуть, це спроба уникнути всезагального осуду або хоча б пом'якшити про себе суспільну думку через письмове пояснення свого вчинку. Психологи стверджують, що такі записки пише майже кожен шостий суїцидент. Частини цих послань адресована конкретним людям, найчастіше найближчим родичам, коханим, друзям, знайомим, рідше - офіційним особам. 


\section{Питання психології}

Більш-менш «сприятливим» місцем для скоєння самогубств є закриті або частково ізольовані від зовнішнього світу специфічні державні інституції та деякі людські осередки. Це військові частини, виправні-трудові колонії, слідчі ізолятори, окремі лікувальні та інтернатні установи, неформальні об'єднання громадян (компанії алкоголіків, бомжів, наркоманів, групи різного роду екстрималів і т.п.), релігійні громади тоталітарного спрямування тощо. В цьому переліку нас цікавлять перш за все військові структури та їхній особовий склад.

Проблема самогубства в армії існує здавна. Колись тут самовбивство вважалось засобом уникнення ганьби у разі військових поразок. Заради відстоювання особистих або корпоративних принципів нерідко прикладали до скроні заряджений пістолет i, не вагаючись, зводили курок офіцери російської царської армії, для котрих здебільшого мали особливі виміри порядність, гідність і честь. Завжди були у кожному війську і так звані «самостріли». Це самогубці із числа тих бійців, хто боявся брати участь у бойових діях, не витримував інших тягарів і складнощів військової служби. А скільки маємо прикладів солдатської і офіцерської самопожертви шляхом закриття своїм тілом ворожої амбразури, самознищення себе i одночасно багатьох оточуючих супротивників вибуховим пристроєм і т.п. Е. Дюркгейм подібний тип суїциду, а саме принесення індивідом себе в жертву заради суспільних інтересів називає альтруїстичним самогубством [8].

Нині до лав української армї призиваються на строкову службу молоді люди у віці 18 років. Саме цей вік вважається надзвичайно складним i відповідальним у плані соціального та професійного становлення особистості. Сувора регламентація способу буття, підвищена вимогливість, що панує в армійському середовищі, тривала відірваність від рідних та близьких, новий незвичний порядок існування i багато іншого викликають у воїнів строкової служби надмірні фізичні, моральні та психологічні навантаження. Останні можуть провокувати появу стресових станів, підвищеної тривожності, депресії, а відтак і спроб суїциду.

Усі конфліктні ситуації у військових колективах, що спонукають до суїцидів, можуть бути кваліфіковані, за висновком Т. Глушкової, таким чином:

1. Конфлікти, зумовлені специфікою військово-професійної діяльності і військово-соціальної взаємодії: індивідуальні адаптаційні труднощі військової служби; зміна умов життєдіяльності; підвищені вимоги до виконання професійних обов'язків; міжособисті конфлікти 3 військовослужбовцями інших періодів служби; брак уваги, турботи з боку оточуючих.

2. Конфлікти, обумовлені специфікою особисто сімейних взаємостосунків військовослужбовця: конфлікти у родині; переживання за можливі наслідки розлучення з коханою, дружиною; зради коханої, дружини; самотність; тяжка хвороба та смерть близьких; інтимно-сексуальні конфлікти.

3. Конфлікти, пов'язані 3 антисоціальною поведінкою військовослужбовця: нестатутні взаємовідносини; побоювання кримінальної відповідальності за скоєний антисоціальний вчинок; боязнь ганьби, насмішок, приниження за невірні дії; самозасудження через аморальний вчинок; почуття провини.

4. Конфлікти, пов'язані зі станом здоров'я: психічні захворювання; хронічні тілесні захворювання; фізичні вади (дефекти мови, особливості зовнішності, які сприймаються як недолік тощо); сексуальна неспроможність та інші ексцеси в інтимних зв'язках.

Людину, в тому числі й військову, нерідко до самогубства штовхають не тільки особисті проблеми, певні конфліктні ситуації, але й так звані побічні чинники. До них можна віднести співчуття та наслідування спокусам друзів, кумирів, героїв книг і кінофільмів, a також співучасть в загрозливих колективних акціях, в яких відбувається 


\section{Питання психології}

балансування між життям та смертю, імітація самовбивства тощо. Зупинимось більш детально на одному 3 таких чинників.

3 90-х років минулого століття в Інтернеті з'явилися сайти самовбивць, де підліткам та молоді пропонується вступити до відповідного віртуального клубу i домовлятися про здійснення одночасних суїцидальних дій. При цьому і вступ до клубу і сам акт суїциду подається у вигляді забавної, спокусливої гри. Перші слова, якими зустрічають відвідувачів сайту (його адресу з відомих причин ми не називаємо), мають такий зміст: «Смерть чарівна. Смерть не меч, що розсікає ваше життя, вона як квітка - остання квітка, яка розквітає в останній момент. Це пік. У смерті не має нічого поганого..., треба знати як жити і як помирати. $Є$ мистецтво жити $і є$ мистецтво помирати, друге найбільш цінне, а ніж перше...» і далі все в такому ж дусі. Потім подається інструкція про правила членства в клубі, а ще пропонується прийняти участь в колективній грі «Смерть у місті». I хоча зараз після серії скандалів такі сайти працюють закодовано і нелегально, знайти ïx при бажанні ні для кого не складає особливих труднощів. Ховаючись за чужими іменами, молоді люди й сьогодні розповідають про те, як їм тісно та незатишно в цьому житті, що вони не бачать майбутнього, не мають цілей для свого подальшого існування і чекають від однодумців відповідних порад. У результаті міжнародна інформаційна павутина робить i надалі свою чорну справу, затягує в павутину смерті схильних до суїциду.

Необхідно мати на увазі, що суїцидальні конфлікти в процесі свого розвитку можуть підлягати генералізації, трансформації або переносу. Завдяки цьому відбувається перехід у військовослужбовця як i в будь-якого іншого суїцидента від внутрішніх до зовнішніх форм суїцидальної поведінки.

Внутрішні форми такої поведінки містять в собі: а) пасивні думки, уявлення, переживання на тему смерті, але ще не на тему умисного позбавлення себе життя.
Вони виникають час від часу майже у кожної людини, проте у більшості випадків надалі відкидаються, замінюються протилежними думками. Інакше ж, в особливо складних життєвих ситуаціях, думки про самогубство у особистості можуть мати постійний прояв, нав'язливий характер i, як правило, трансформуватися в подальші варіації психічного процесу; б) суїцидальні задуми i наміри, які набувають вигляду сталої тенденції. Задуми - це обміркування засобів суїциду, часу i місця його здійснення та інших питань, пов'язаних із запланованим самовбивством. Наміри передбачають практичну готовність до суїциду, приєднання до задуму вольового компоненту.

Зовнішніми формами суїцидальної поведінки є реальні спроби самогубства та завершені суӥциди. На цій стадії можна отримати два результати. Перший бажаний для оточуючих - коли людина самостійно або при втручанні інших людей перериває чи відкидає спробу до самознищення або в певний момент припиняє акт суїциду. Другий небажаний - коли спроба вчинити самознищення завершується летальним кінцем.

Військова практика фіксує різноманітні методи суїциду: вогнепальні поранення, самоповішення, самоотруєння, самопорізи, падіння 3 висоти, самовтоплення, самоспалення, електротравми та інше. Зрозуміло, що більшість самогубств в армії здійснюється з використанням зброї.

Варто відрізняти істинні суїцидальні ризики від демонстративно-шантажних дій, коли індивід не ставить собі мету позбутися життя, а лише бажає через незначні тілесні пошкодження вплинути на оточуючих, привернути увагу до власної персони, вирішити конкретну проблему на свою користь.

Про істинність же суїцидальних намірів військовослужбовця свідчать, як правило, наступні показники: 1) заздалегідь вироблений план лишити себе життя; 2) посилені міри застережності, що здійснюються 3 метою запобігання 


\section{Питання психології}

розкриття задуму; 3) відсутність спроб отримати допомогу під час або після здійснення суїциду; 4) повторюваність суїцидальних спроб; 5) активні, а не пасивні дії по самознищенню; 6) використання небезпечних засобів причинення собі шкоди; 7) наявність посмертної записки або заповіту; 8) стійкість і незмінюваність суїцидальних намірів.

$$
\text { Виділимо наявні ознаки }
$$

суӥцидальності у військовослужбовця, це:

1.Імпульсивний: раптове прийняття особою драматичних рішень під час виникнення проблеми $\mathrm{i}$ стресових ситуацій; наявність труднощів у словесному виразі емоційних переживань.

2. Компульсивний: прагнення $\mathrm{y}$ всьому досягти досконалості i успіху; виникнення труднощів при співвідношенні цілей та бажань 3 реальною ситуацією; будь яка зміна життя у такої особи в гіршу сторону може привести до суїциду.

3. Ризикуючий: балансування на межі загрози є привабливим і викликає приємне збудження; людина 3 таким стилем гравець зі смертю.

4. Регресивний: зниження 3 різних причин механізмів психологічної адаптації; емоційна сфера характеризується недостатньою зрілістю і виразною примітивністю.

5. Залежний:

безпорадність, безнадійність, пасивність, необхідність і постійний пошук сторонньої підтримки.

6. Амбівалентний: наявність одночасного впливу двох спонукань - до життя і до смерті.

7.Заперечуючий: превалювання магічного мислення, яке схиляє особу до заперечення кінцівки самовбивства і його наслідків; заперечення призводять до зниження контролю над вольовими спонуканнями що збільшує ризики суїциду.

8. Гнівний: відчуття труднощів у вираженні гніву по відношенню до значущих осіб, а також незадоволення до самого себе, за те, що відчувається гнів.

9. Звинувачуючий: Звинувачування всіх і вся, у тому числі і себе особисто в усіх бідах, складних питаннях, життєвих проблемах тощо.

10. Утікаючий: втікання від важкої ситуації за допомогою самогубства, стремління уникнути або покинути травмуючи обставини.

11. Нечутливий: притуплення емоційних переживань.

12. Покинутий: відчуття

самотності, переживання порожнечі навколо себе, постійне сумування, скорбота з цього приводу.

13. Творчий: сприйняття самовбивства як нового і дуже вдалого засобу вийти з патової ситуації.

Парадокс суїциду заклечається в тому, що задумане самознищення наповнюється для самовбивці, у тому числі i в армійських умовах, певним морально-психологічним змістом. Як заключає В. Тихоненко, існує п'ять основних типів особистісного сенсу самогубства: «протест», «заклик», «уникнення», «самопокарання» i «відмова» [9].

Зміст суӥцидів типу «протест» зводиться до бажання самовбивці покарати кривдників, причинити їм шкоду хоча б фактом своєї смерті.

Сутність суїцидальної поведінки, яка має назву «заклик» полягає в тому, щоб активізувати реакцію оточуючих, викликати у них своєю смертю співчуття, жаль тощо.

Суїциди типу «уникнення» забезпечують як би відхід людини від нестерпної загрози іiі існування (невиліковної хвороби, неминучого покарання, ганьби та ін.).

Суїциди типу «самопокарання», можна охарактеризувати, як результат двобою у внутрішньому світі індивіда двох протилежних «Я»: «Я-судді» і «Япідсудного». Звичайно, в ході такого протиборства в разі накладання особою на себе рук настає або летальний кінець, або отримуються тілесні ушкодження.

Що стосується суїцидів типу «відмова», то їм притаманна повна капітуляція людини перед тяжкими обставинами, так би мовити, здавання іiі відразу в «полон» смерті. 


\section{Питання психології}

В реальній ситуації реакції самогубців, як правило, тяжіють до якогось одного із названих типів.

Таким чином, як попередня, так i дана інформація дозволяє військовим психологам, командирам, фахівцям 3 виховної роботи більш впевнено, професійно орієнтуватись в психологічних нетрях підлеглих, які схильні до самогубства.

Важливо також знати, що практично жодна людина не вчиняє суїцидального акту, не давши про це знати оточуючим. В реальному житті явних симптомів, що засвідчують підготовку військовослужбовця до самогубства дуже багато. Наведемо основні 3 них, зауваживши при цьому, що більшість таких прикмет нами віднайдено в інформаційно-методичній літературі [4], [5], [8]. До цих ознак належать:

- відкриті висловлювання про бажання покінчити з собою (товаришам по службі, командирам, у листах до родичів, близьких людей, знайомих);

- непрямі «натяки» на можливість скоєння суїциду - «репетиція самогубства» - прилюдна демонстрація петлі з ременя чи штанів, мотузки та ін., гра зі зброєю з імітацією самогубства;

- активна попередня підготовка, цілеспрямований пошук засобів покінчити 3 собою і створення умов (накопичення лікарських засобів, залишення i приховування патронів після навчальних стрільб, пошук i зберігання отруйних речовин, зміцнення мотузки тощо);

- фіксація на прикладах самогубства (підвищений інтерес, зацікавленість, часті розмови про самогубство взагалі);

- порушення міжособистісних стосунків, звуження кола контакту у військовому колективі, прагнення до усамітнення;

- надзвичайно наполегливі прохання про переведення до іншого підрозділу, про госпіталізацію, надання відпустки за сімейними обставинами;

$$
\text { - часті звертання }
$$

військовослужбовця до рідних і знайомих 3 проханням направити до військової частини «фіктивну» телеграму про важке сімейне становище;

- зміни у поведінці: непритаманна замкнутість та зниження рухливої активності - у рухливих («зловісний спокій» i зібраність), збентеження та підвищена активність спілкування - у малорухливих і мовчазних;

- порушення міжособистісних стосунків, звуження кола контактів у військовому колективі, прагнення до усамітнення аж до повного відречення від оточуючого середовища;

- раптовий прояв неправильних рішень військовослужбовців рис охайності, відвертості, щедрості (роздавання особистих речей, що часто супроводжується символічним прощанням);

- міркування на тему самогубства шляхом використання «художніх» прийомів (зображення у записниках, зошитах для занять малюнків, що ілюструють депресивний стан труни, хрестів тощо);

- розпорошеність уваги, нудьга, зловживання алкоголем, ліками, споживання наркотиків;

- прояви деяких ознак дитячої поведінки (інтонації в голосі, роздратованість та ін.);

- настирні пошуки номерів телефону відповідної соціальної служби для інтимного консультування або безпосереднє звернення по «телефону довіри».

Одним із важливих показників можливості суїциду $є$ емоційні переживання людини. Більшість потенційних самогубць страждають від депресій. Депресія - це афективний стан людини для якої характерній негативний емоційний фон, кардинальні зміни мотивації та когнітивних уявлень, загальна негативність поведінки. Значна депресія у суїцидентів починається поступово, спочатку з'являється тривога i в'ялість. Люди можуть не усвідомлювати це. Вони тільки помічають, що останнім часом стали подавленими, сумними i хандрять. Майбутнє постає темним, дані особи вважають, що його неможливо 


\section{Питання психології}

змінити самостійно, приходять до висновку, що хворі раком, психічною чи іншою невиліковною хворобою. Самогубці перед суїцидом часто думають про смерть. Їм стає важко виконувати навіть прості обов'язки. Кажуть: «Я навіть не можу ясно мислити». Вони не мають змоги прийняти найпростіше рішення, скаржаться на в'ялість, нестачу життєвої енергії та втому.

Про свідчать, зазвичай, такі ознаки:

- втрата апетиту або інтенсивне переїдання, безсоння або підвищення сонливості протягом, в крайньому випадку, останніх днів;

- відчуття нудьги при проведені часу в звичайному оточені або при виконанні роботи, яка раніше приносила задоволення;

- раптові приступи гніву, які часто виникають із-за дрібниць;

- порушення уваги зі зниженням якості виконуваних завдань і обов'язків.

А особливо загрозливим для життя військовослужбовця, який обирає шлях суїцидента, вважаються прикмети наступного змісту:

- впадання в повну депресію, відчуття власної нікчемності;

- тунельна свідомість;

- визначення ідеї в який спосіб, де і коли буде здійснюватись самознищення i відкрите приготування до нього;

- постійні погрози, заяви типу: «Я не можу більше цього витримати», «Я не хочу більше жити», «Я хочу померти» $\mathrm{i}$ т. п.;

- реальне прощання 3 оточуючими людьми.

Якщо не звертати увагу на «сигнали» можливого суїциду, то кожний випадок самогубства може стати трагічною несподіванкою.

На основі різноманітних проявів поведінки можна вчасно виявити військовослужбовців 3 різним ризиком суїцидальних дій.

Найбільш важливими напрямками в психологічній роботі із суїцидентами $\epsilon$ діагностика і профілактика самогубства. В армії цими питаннями повинні предметно займатися не тільки військові психологи, командири та начальники але й товариші по службі, знайомі, родина воїна. Надання психологічної допомоги військовослужбовцям, які схильні до суїциду чи здійснили спробу самогубства покладається насамперед на психологічну службу військової частини.

На наш погляд дуже вдалою $\epsilon$ методика визначення ризику суїцидальності військовослужбовця яка міститься у збірнику «Технології соціальної роботи 3 військовослужбовцем» [8].

Завдяки їй військовий психолог виявляє і оцінює ризики самогубств, які розрізняються на незначні (наявність суїцидальних думок без конкретних планів), середні (наявність таких думок i плану без терміну реалізації) і високі (є думки, розроблений план, продумані терміни та засоби його реалізації.

Що стосується профілактики суїцидальних то ця робота має бути системною, базуватись на виробленні конкретної превентивної стратегії.

Діяльність практичного психолога у війську 3 питань запобігання суїцидів включає декілька профілактичних рівнів: загальний, первинний, вторинний i третинний.

На етапі загальної профілактики суїциду психолог здійснює наступні заходи:

- вивчає особливості соціальнопсихологічного стану i адаптації військовослужбовців 3 метою своєчасної профілактики та ефективного подолання труднощів;

- бере участь у створенні системи психологічного супроводу військовиків (розв'язання конфліктів, психологопедагогічна підтримка, психологічне консультування і т. ін.);

- надає поради, рекомендації під час розробки й проведення різних заходів, метою яких $\epsilon$ сприяння формуванню позитивного образу «Я», унікальної i неповторної особистості, комунікативної компетентності, ціннісного відношення до життя тощо. 


\section{Питання психології}

Первинна профілактика суӥциду здійснюється стосовно військових так званої початкової «групи ризику» (наявні три i більше факторів суїцидального ризику). Не можна стверджувати, що ці особи обов'язково будуть реалізовувати суїцидальні наміри, проте, враховуючи комплекс суїцидальних факторів, необхідно стосовно цієї групи обов'язково вести профілактичні дії.

у першу чергу працівникам психологічної служби варто організувати комплекс заходів, що сприятимуть підвищенню компетентності команди та колег по службі стосовно розпізнання маркерів суїцидального ризику та надання підтримки військовослужбовцям, які опинились у складній життєвій ситуації.

3 метою психологічної просвіти членів військового колективу та родини розробляються пам'ятки, які містять інформацію про те, як розпізнати гострий кризовий стан у людини і що робити, коли вона висловлює суїцидальні наміри. У військові колективи психологами запрошуються медичні працівники для проведення лекцій та бесід 3 проблем депресії і суїцидального ризику.

Практичними психологами також складаються і реалізуються індивідуальні програми супроводу військовослужбовця, що потрапив в коло суїцидентів.

Вторинна профілактика суїцидальної поведінки здійснюється 3 групами військовослужбовців різного рівня ризику,тобто тими, які проявляють опосередковано інтерес до суїциду або прямо говорять про суїцидальні наміри, чи мають конкретний план здійснення самознищення. Основна іiі мета запобігання самогубства.

Залежно від рівня суӥцидального ризику психологами застосовуються відповідні дії. При незначному ризику суїциду практичний психолог пропонує військовослужбовцю емоційну підтримку, припрацьовує суїцидальні почуття, фокусує увагу на сильних сторонах особи,організує зустрічі суӥцидентам 3 психотерапевтами, психіатрами та іншими спеціалістами.
При середньому рівні ризику суїциду, окрім здійснення вже названих заходів, психолог обговорює 3 клієнтом альтернативи самогубства, укріпляє бажання жити, встановлює зв'язок 3 родиною, друзями, заключає відповідний контракт.

При високому рівні ризику суїциду практичний психолог постійно знаходиться 3 військовослужбовцем, спостерігає за його станом, обмежує доступ до можливих засобів самогубства, організує госпіталізацію клієнта, інформує родину.

Третинна профілактика суїциду передбачає заходи, які б знизили наслідки та зменшили вірогідність парасуӥциду, посилили соціальну та психологічну реабілітацію суїциданта. Здійснюється вона $з$ тим хто вже вчинив спробу суїциду та за умови збереження джерела болю (фрустрації, конфлікту тощо) може піти на другу спробу «втечі» від проблеми. Практичний психолог на етапі третинної профілактики суїциду проводить таку роботу:

- визначає тип постсуїцидального стану клієнта;

- розробляє алгоритм соціальнопсихологічного супроводу (в тому числі із залученням медичних працівників);

- бере участь у роботі консиліуму щодо суїцидального випадку (в організації та роботі антикризової команди);

- здійснює індивідуальну корекційну роботу 3 клієнтом (за розробленою та затвердженою керівником психологічної служби програми);

- організуе групову роботу 3 включенням в неї суїцидента 3 метою відновлення навиків адаптації (комунікативний тренінг, тренінг фрустраційної толерантності);

- консультує командирів та батьків (консультування в рамках антикризового штабу);

- веде моніторинг емоційного стану суїцидента (методом спостереження, інтерв'ю, опитування).

Самогубці-військовослужбовці зазвичай, психічно здорові люди, які, не знайшовши підтримки в людському 


\section{Питання психології}

соціуму, «заграють» зі смертю. На жаль, українці ще не звикли звертатися за порадою до психолога. Саме він у хвилини незлагоди із самим собою зміг би справді допомогти.

Будь-який командир, звісно, відповідає не тільки за високу боєздатність ввіреного йому підрозділу або військової частини в цілому, за створення матеріально-побутових умов для підлеглих, але і за здоровий моральнопсихологічний клімат в колективі. Посправжньому батьківське опікування кожного воїна, знання його психологічних настроїв - прямий обов'язок командира i начальника. Зрозуміло, що тут без володіння певними психологопедагогічними навиками посадовим особам не обійтись.

Складовою роботи 3 профілактики суӥцидальних прояв серед військовиків i обов'язковою $\epsilon$ профілактична бесіда, необхідність якої виникає 3 моменту виявлення клієнтів, які перебувають у передсуїцидальному стані. Командиру для запобігання спроби самогубства підлеглих важливо вчасно встановити з особою, яка, потрапила у біду, людяний, довірливий контакт, вступити 3 ним у товариське спілкування.

Бесіди 3 клієнтом,який перебуває у стані психологічної кризи - справа дуже тонка, специфічна i потребує старанної,попередньої підготовки. Для більшої ефективності вона повинна складатися 3 кількох послідовних етапів, кожний 3 яких має своє специфічне завдання i передбачає використання специфічних прийомів.

Сдине попередження не бути психіатрами-любителями, не давати ніяких порад людям з розладами психіки. Тільки після закінчення заключення психолога і лікаря дозволяється проводити профілактичну роботу 3 підлеглими. Насамперед слід з'ясувати причину, такої реакції, i намагатись усунути іiі або максимально пом'якшити.

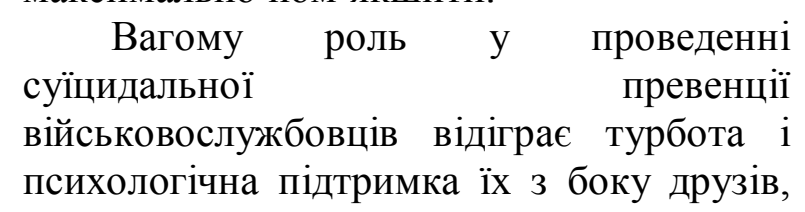

знайомих, рідних, а також самодопомога. Суїциденти страждають від сильного почуття соціальної ізоляції та відчаю. Вони потребують обговорення свого болю, фрустрації, розуміння власних проблем. Іноді людині, що перебуває у кризовій ситуації, потрібний лише уважний добрий слухач. Друзі повинні допомагати ій визначити витоки психологічного дискомфорту, пропонувати альтернативні рішення проблем. Емоційні проблеми, що призводять до суїциду, рідко вирішуються швидко і головне завдання друзів - не залишати суїцидента наодинці, доки він повністю не адаптується до життя.

При наданні відповідної допомоги потенційному суїциденту можуть знадобитись його командиру, рідним i друзям наступні практичні рекомендації:

1. Завжди підбирайте «ключі» до розгадки суїциду. Суїцидальна превенція полягає не лише в участі по наданню допомоги, а й у здатності розпізнати ознаки можливої небезпеки: суїцидальні погрози, які передують спробі самогубства: депресія, значні зміни поведінки чи особистості людини, а також приготування до останнього волевиявлення. Відзначте прикмети безпомічності й безнадії і з'ясуйте, чи не $€$ ця людина самотньою та ізольованою.

2. Прийміть суїцидента як особистість. Припустіть, що, людина є дійсно суїцидальної особистістю. Не думайте, що вона не здатна і не зможе наважитися на самогубство.

3. Якщо ви думаєте, що комусь загрожує небезпека самогубства, дійте згідно зі своїми власним и почуттями й переконанням. Небезпека, що ви перебільшите потенційну загрозу, - ніщо в порівнянні з ти, що хтось може загинути через ваше невтручання.

4. Налагодьте турботливі стосунки. У цій ситуації $\epsilon$ час для доброзичливої підтримки, яку потрібно висловлювати не лише словами,а й діями. У подальшому дуже багато залежатиме від якості ваших стосунків. Для того, хто відчуває, що він нікому не потрібний, турбота чуйної людини $\epsilon$ могутнім підбадьорливим засобом. Саме приймаючи таку людину, 


\section{Питання психології}

ви зможете проникнути в іï ізольовану душу.

5. Будьте уважним слухачем. Якщо людина перебуває в депресійному стані, їй більше потрібно говорити самій,аніж слухати когось. Вона страждає від сильного почуття відчуження і не завжди готова сприйняти ваші поради, відгукнутися на ваші думки і потреби.

6. Не засуджуйте таку людину, пам'ятайте, що їй важко зосередитися на чомусь окрім своєї безвиході. Вона хоче позбутися болю, але не може знайти виходу. Спробуйте залишитися спокійним і розуміючим. Ви можете надати безцінну допомогу, вислухавши розповідь про почуття цієї людини.

7. Не сперечайтеся. Зустрічаючись iз суїцидальної загрозою, керівники, друзі, родичі часто відповідають: «Подумай, ти живеш набагато краще, ніж інші, ти мав би дякувати долі» або «Ти розумієш, які нещастя і сором чекають на твою родину, або твій колектив». Такі відповіді одразу блокують подальше обговорення i викликають у нещасного ще більшу пригніченість. Бажаючи допомогти таким чином, співбесідники сприяють зворотному ефекту.

8. Нi в якому разі не виявляйте агресії, якщо ви присутні під час розмови про самогубство, i спробуйте не висловлювати обурення тим, що почули.

9. Частіше запитуйте суїцидента. Найкраще запитати: «Ти думаєш про самогубство?». Це не викличе подібної думки, якщо іiі раніше не було. Але якщо людина думає про самогубство i знаходить когось, кому небайдуже i. хвилювання і хто згодний обговорити цю заборонену тему, то вона часто відчуває полегшення, одержує можливість зрозуміти свої почуття й досягнути катарсису.

10. Не пропануйте не виправданих утіх. Причина із якої суїцидент посвячує у свої думки, полягає у бажанні викликати занепокоєність його ситуацією. Якщо ви не виявите зацікавленості й чуйності, то депресивна людина може вважати судження на зразок: «Ви насправді так не думаєте», - виявом зневаги й недовіри. Суӥциденти 3 презирством ставляться до зауважень типу: «Нічого, в інших є такі самі проблеми, як і в тебе», оскільки вони різко контрастують із їхніми стражданнями. Подібні фрази лише принижують їхні почуття i примушують відчувати себе ще більш непотрібними.

11. Пропонуйте конструктивні підходи. Допомогти суӥциденту визначити джерело психічного дискомфорту важко. Адже наміри бувають різні.

12. Зверніться по допомогу до спеціалістів.

13. Вселяйте надію.

14. Пам’ятайте! «В дев'яти випадках 3 десяти суїцидальна спроба-це не бажання покінчити 3 життям, а крик по допомогу» (Г. Отто).

Висновки та перспективи подальших досліджень. Викладений матеріал дозволяє зробити такі основні висновки:

1. Суїцидальна поведінка людини взагалі і військовослужбовця зокрема-це психічна хвороба.

2. Джерело самогубства криється в душевному неблагополуччі індивіда, пов'язаному, насамперед, зі складністю його буття, в соціально-психологічній дезадаптації людини в умовах гострої мікросоціальної конфліктної ситуації.

3. Самогубство має свою історію, теорію i практику,а також перспективу подальшого існування і розвитку. poботі.

Про все це та інше йшла мова у даній

Потенційного суїцидента, в тому числі й військовослужбовця, можна вивести iз будь-якого кризового душевного стану, головне - це своєчасно почути, розпізнати тривожні симптоми, зняти або пом'якшити конфліктні життєві ситуації. Для цього посадовим особам, товаришам по службі, рідним необхідно чітко орієнтуватись в причинах, тенденціях, формах i основних ознаках суїцидальної поведінки особистості та заходах стосовно їі профілактики.

Певну допомогу у цьому відношенні може надати дана наукова робота, в якій зроблена спроба всебічно розкрити теорію питання та сформувати відповідні практичні рекомендації. 


\section{Питання психології}

\section{Список використаних джерел}

106.

1. Бердяев Н.А. О самоубийстве. [Текст] / Психологический журнал № 3. - 1992. - С. 96 -

2. В поисках смысла. [Текст] / Сост. А.Е. Мачехин. Изд. 2-е, перераб. и доп. - М.: ОЛМА ПРЕСС, 2005. - $912 \mathrm{c}$.

3. Глушкова Т.О. Профілактика суїцидів у військових частинах. [Текст] / Практична психологія і соціальна робота - 2000. - № 1, № 2. - С. 26 - 30, С. 27 - 29.

4. Методичні рекомендації з надання психологічної допомоги молоді, яка схильна до суїциду, чи здійснила спробу суїциду. [Текст] / Упорядник Лазаренко Б.П. - К.: УДЦССМ, 1998. - 44 с.

5. Причина суїцидальної поведінки. Методичні рекомендації. [Текст] Старокостянтинів, 2007. $-13 \mathrm{c}$.

6. Рыбалко Н.В. Проблемы суицида в молодёжной среде. [Текст] / Молодёжь и будущее Украины. Материалы первой Всеукраинской студенческой научно-практической конференции (г. Донецк, 15. 04. 2003 г.) Отв. ред. В.И. Носков. Донецк, ДНУ, 2003. - С. 141 - 142.

7. Суицид. Хрестоматия по суицидологии. [Текст] Под ред. А. Моховникова, К.: УДЦССМ, 1994. -602 c.

8. Технологія соціальної роботи з військовослужбовцями: [Текст] Інформаційно-методичний збірник / Упорядник I.В. Паша. - К.: УДЦССМ, 2003. - 335 с.

9. Тихоненко В. А. Жизненный смысл выбора смерти. [Текст] / Человек. - 1992. - № 6. - С. $19-29$.

\section{References}

1. Berdiaev N.A. About suicide [O samoubyistve]. Psykholohycheskyi zhurnal No. 3. - 1992. - p. $96-106$.

2. Machekhyn A.E. In search of meaning [V poyskakh smysla]. 2nd ed. - M.: OLMA - PRESS, 2005.

3. Hlushkova T.O. Prevention of suicides in military units [Profilaktyka suitsydiv u viiskovykh chastynakh]. Praktychna psykholohiia i sotsialna robota - 2000. - No. 1, No. 2. - p. $26-30$, p. $27-29$.

4. Lazarenko B.P. Methodical recommendations for providing psychological assistance to young people who are susceptible to suicide, or attempted suicide. [Metodychni rekomendatsii $\mathrm{z}$ nadannia psykholohichnoi dopomohy molodi, yaka skhylna do suitsydu, chy zdiisnyla sprobu suitsydu]. K.: UDTsSSM, 1998.

5. The cause of suicidal behavior. Guidelines. [Prychyna suitsydalnoi povedinky. Metodychni rekomendatsii], 2007. Starokostiantyniv.

6. Rybalko N.V., 2003. Problems of suicide in the youth environment [Problemy suytsyda v molodezhnoi srede]. In: Donetsk DNU, Youth and the future of Ukraine. Materials of the first AllUkrainian Student Scientific and Practical Conference. [Molodezh y budushchee Ukrayny. Materyaly pervoi Vseukraynskoi studencheskoi nauchno-praktycheskoi konferentsyy] Donetsk, 15.04.

7. Mokhovnykova A.M. Suicide. Readings on suicidology. [Suytsyd. Khrestomatyia po suytsydolohyy]. K.: UDTsSSM, 1994.

8. Pasha I.V. Technology of social work with servicemen: Informational and methodical collection [Tekhnolohiia sotsialnoi roboty $\mathrm{z}$ viiskovosluzhbovtsiamy: Informatsiino-metodychnyi zbirnyk]. K.: UDTsSSM, 2003.

9. Tykhonenko V.A. The life meaning of the choice of death [Zhyznennyi smysl vybora smerty]. Chelovek. - 1992. - No. 6. - p. $19-29$.

\section{Резюме}

Семенов С. кандидат философских наук, доиент, Национальная академия Национальной гвардии Украиньь

Слурденко Д.О. Наџиональная академия

Начиональной гвардий Украинь

Шевченко В. Национальная академия

Начиональной гвардий Украиньл

ПСИХОЛОГИЧЕСКИЙ АНАЛИЗ ПРОБЛЕМЫ СУИЦИДАЛЬНОГО ПОВЕДЕНИЯ ВОЕННОСЛУЖАЩИХ

Сделана попытка раскрыть общее понятие суицида, дать психологическую характеристику основных составляющих суищидального поведения военнослужащих и рассмотреть организацию 


\section{Питання психології}

психологической работь по диагностике и профилактике проявления самоубийства членами воинских коллективов.

Ключевые слова: суищид; соччиально-психологическая дезадаптаџчия; военнослужащчий.

\section{Summary}

Semenov $S$. Candidate of philosophy sciences,

Associate Professor National Academy of National Guard of Ukraine

Slurdenko D. National Academy of National Guard of Ukraine

Shevchenko $V$. National Academy of National Guard of Ukraine

\section{THE PSYCHOLOGICAL ANALYSIS OF THE PROBLEM OF SUICIDAL BEHAVIOR} AMONG MILITARY PERSONNEL

Introduction. According to the World Health Organization's forecast for 2020, approximately 1.5 million people on earth will commit suicide. Statistics say that about 500 suicidal attempts occur every day in Ukraine, resulting in 35-40 deaths. We have more people die from suicide than by murderers ' hands and after car accidents. There has long been a problem of suicide in the National Guard of Ukraine. Rigid regulations, compulsory military service, significant psychological and physical pressure, the impact of negative trends in society on the military environment, acute shortages of qualified psychologists etc. causes provoke suicidal behavior among military personnel.

At this stage, the nature of suicidal activity and its prevention in military society is being actively studied in the scientific environment.

Purpose. The purpose of the study is to consider the concept of suicide, to determine the psychological characteristics of the main components of suicidal behavior of military units and to consider the organization of psychological activity for diagnostics for the prevention of suicidal activity among military personnel.

Methods. Analysis and synthesis, comparison, generalization.

Originality. We have improved the theoretical and psychological approach of studying the suicidal behavior of a serviceman and have considered the organization of psychological work on the diagnosis and prevention of suicidal activity in military personnel.

Conclusion. The presented material allows us to make the following conclusions:

1. Suicidal behavior of a person in general and a serviceman in particular is a mental illness.

2. The source of suicide activity is in emotional distress of a person first of all caused by complexity of his being, social and psychological maladaptation of a person in an acute micro-social conflict situation.

3. The social phenomenon of suicide has its history, theory and practice, as well as the prospect of its further existence and development.

A person who plans to commit suicide, including a serviceman, can be removed from any crisis state of mind. The main thing in this matter is to hear in a timely manner, to recognize disturbing symptoms, to resolve or to mitigate conflicting life situations. To do this, officials, co-workers, relatives need to be clear about the causes, tendencies, forms and main features of suicidal behavior of the individual and measures to prevent it.

Some assistance in this issue may be provided by this research work, which attempts to comprehensively uncover the theory of the issue and formulate appropriate practical recommendations.

Key words: suicide; psychosocial maladjustment; soldier. 